\title{
NATURE PROTECTION IN THE NEAR AND MIDDLE EAST
}

$\mathrm{D}^{\mathrm{t}}$ URING June 3-9 a conference on the conservation of Nature in the Near and Middle East was held at Beirut, organized by Prof. F. Ghosn, president of the Lebanese Society of the Friends of the Trees, and Mr. W. E. Purnell, director of the Unesco Middle East Scientific Co-operation Office. The conference was attended by scientists and others from Cyprus, Egypt, Greece, Iraq, Jordan, Lebanon, Syria and Turkey. Dr. E. H. Graham, director of plant ecology, Soil Conservation Service, United States Department of Agriculture, attended from Washington, D.C., and Lieutenant-Colonel C. L. Boyle went from London on behalf of the Society for the Promotion of Nature Reserves and the Fauna Preservation Society. Many of the participants are actively engaged in conservation problems in their own countries and, at the conference, had an opportunity to exchange opinions and discuss experiments. After a short general discussion, study groups were formed to consider separately soil, flora, fauna and education.

The discussions of the soil and flora groups showed that, although great damage had been done to the forests of the Near and Middle East, they had not been utterly destroyed. M. P. Ballot, head of the French Agricultural Mission to the Lebanon, said that they had only just realized the continued existence in the Anti-Lebanon mountains of a juniper forest of perhaps a million trees ; furthermore, experiments had shown how extraordinarily quickly vegetation could re-establish itself when it was protected from grazing. A distinction can be drawn between the damage done by the grazing of sheep and of goats; whereas trees can grow fairly quickly beyond the reach of browsing sheep, goats, as was shown by a photograph of them feeding high in an oak tree, can reach almost anything.

The flora group pointed out that in much of the area, the climate is not sufficiently arid to explain the lack of vegetation; but even where the rainfall is adequate, the destruction of the plant cover has resulted in the water being lost by immediate runoff, deep percolation and evaporation. Moreover, it is not only the quantity of plants which matters. Where grazing is heavy, perennial grasses with spreading root systems, which bind together the soil, build up humus beneath the surface and retain moisture, are replaced by annual grasses which do nothing to resist erosion. Similarly, forests are replaced by thorny shrubs with tapering roots, which do little to conserve the soil. The annuals and the thorny shrubs survive because they can resist grazing.

It is fully understood that complete elimination of goats is not possible, for they play an important part in the economy of the area; but their number must be radically reduced. Mr. Y. Salti, director of forests, Jordan, explained how goat control is effected in his country. When a considerable majority in a village vote against goats, they are restricted to three tethered goats per family. In practice, the reduction in goat population is not easy, for it is the shepherds who own not only the goats but also the village rifles.

The chief factor in the destruction of the forests has been the demand for fuel; but preservation is linked with the economic betterment of the people. A man blamed for cutting good, bearing olive trees said, "What am I to do ? I have a large family and absolutely nothing with which to provide them with food, but the immediate value of these trees".

Wood is cut for many purposes besides domestic burning - for charcoal burning, for firing of bakeries and lime kilns. That these can be brought under control has been shown by the example of Cyprus. Oil is the alternative to wood, but for domestic use oil alone is of little value. The production of a really cheap crude-oil stove would be a major step towards the prevention of soil erosion. The solar stove, which cooks by the sun's rays, is considered to be a possible answer to the problem, but so far its cost has been prohibitive.

The fauna study group, working under the chairmanship of Prof. C. Kosswig, of Istanbul, were told how the recent killing of pelicans on Lake Marmara has resulted in such competition for food among young carp that their growth has been retarded and none has reached full size. A very interesting report came from Cyprus, where natural regeneration of the forests of Pinus nigra, confined to altitudes above four thousand feet, has failed. In spring, when the warm khamsin wind blows, the cones open and discharge their seeds, which, clearly visible on the snow, are eaten by hordes of migratory finches. Possibly destruction of hawks, which controlled the number of finches, has led to the failure of the natural regeneration of the pines.

Egyptian scientists directed attention to the dangers inherent in the excessive use of poison sprays and insisted that nature reserves should contain as many kinds of habitat as possible, including ponds for the protection of water insects. They recommended special protection for the desert monitor and the four large lizards of the genus Uromastix, the only herbivorous lizards; these are in danger of extermination because they are being used in laboratory work, for which smaller lizards would do equally well. Stress was laid on the im. portance of instruction in the mosques, for the fellaheen are very responsive and have great faith in their religious teachers.

Among the recommendations of the fauna group was that a questionnaire should be sent to appropriate schools in Turkey, to discover the status of the rare monk seal, which still appears every year on the coasts. Similar methods in other cases have produced good results. An investigation into the status of the rock hyrax in Lebanon, with the view of its preservation, was also suggested. Many mammals were recommended for protection-for example, the leopard, lynx and jungle cat in Turkey and the wild ass and addax in Egypt, where they still exist on the Sudan border. Reserves for wild life were recommended at Kammouha in the Lebanon, in the province of Lattakia in Syria and at Wadi-el-Natroun and Wadi-el-Assioti in Egypt.

All governments were advised to safeguard rivers against pollution. Though rivers in this part of the world may not yet have been affected, it is a danger to be guarded against as industrialization progresses. Destruction of fish by poison and explosives will 
never be stopped until fish wardens are appointed and the public instructed in conservation.

During a visit to the best-known group of cedars in Lebanon, it appears that grazing in their vicinity has been stopped; nevertheless, there was little sign of regeneration, prevented perhaps by human trampling. The conference was shown research work at the Franco-Lebanese agricultural college at Ryak and, on the coast, research into the fixation of sand-dunes by grasses backed by plantation of the umbrella pine, Pinus pinea.

A full report of the conference will be prepared by the Unesco Middle East Science Co-operation Office, and suggestions for the implementation of the resolutions sent to appropriate bodies.

\section{L. Boyle}

\section{PROGRESS OF CANCER RESEARCH}

7 HE investigations under way at the research centres financed by the British Empire Cancer Campaign are described in its thirty-first annual report*; incidentally, it may be remarked that the Campaign's income in 1953 was $£ 350,000$, which is about the cost of one air liner.

The different lines of work surveyed in the report can be grouped into those dealing with : $(a)$ carcinogenesis, eytotoxins, nucleoproteins (in the laboratory light-heartedly referred to as 'secret-of-life studies'), tissue culture and immunology ; $(b)$ radiotherapeutics and radiobiology ; (c) clinico-pathology.

The explanation for the ominous increase in lung cancer in the past two or three decades continues to be the principal theme of general interest in cancer research.

Emphasis has now shifted slightly from cigarette smoking as a very important factor in the causation of the disease to the influence of atmospheric pollution. This does not mean that experiments on the tobacco factor have ceased; far from it, for at several laboratories mechanical smoking installations have been set up with the aim of obtaining in quantity the components of tobacco smoke and testing them on animals. One of the main problems is, of course, to find an experimental tissue with the same sensitivity as human lung.

Tobacco extracts reinforced by croton oil havo failed to induce tumours when applied to mouse skin. The complementary experiment when the extracts were tested as possible co-carcinogen for dimethylbenzanthracene also gave negative results.

The inhalation of carcinogen-loaded charcoal has not induced lung cancor in a single mouse of eightyfive which survived a minimum of six months, although the same charcoal suspension was actively tumour inducing when injected subcutaneously. It is suggested that the negative result is duo to the carcinogen not reaching the parenchyma but being rapidly removed from the bronchial tree. This explanation could be confirmed by the fluorescence microscopy of frozen sections.

At the Glasgow centre it was found that application of crude oxidized nicotine to the skin of fourteen mixed-stock mice gave adenomata of the lung in seven of the animals. This remarkable result soems to have induced a hypercritical state in the investigators, Schontal and Head, for they say, "However,

* British Empire Cancer Campaign. Thirty-first Annual Report covering the Year 1953. Pp. xxxiv +468. (London: British Empire Cancer Campaign, 1954.)

these results may not be significant, and should be repeated using a different strain of mice as well as other species of animal".

The part played by industrial and domestic smoke in the causation of lung cancer is discussed in Sir Ernest Kennaway's review of atmospheric pollution in Iceland, Britain and Norway.

"Great Britain has stores of coal and iron which have been the source of vast wealth, and of many other consequences. Iceland, which has no such resources, and has not even abundance of any kind of fuel except peat, has a history, and a degree of civilization which all other countries must admire, without industrialization or poverty as we understand these things in many countries of Europe and America. Hence data from a country such as Iceland are of great value for comparative purposes. The Industrial Revolution which in the earlier part of the 19th century converted England, by the utilization of coal and iron, from an agricultural to an industrial country, caused an enormous increase in atmospheric pollution. Obviously this factor cannot, by itself, account for the sudden increase of deaths attributed to cancer of the lungs which occurred a century later, in the 1920's, when the output of smoke was declining. Recently the greater part of this increase, and the higher incidence of this form of cancer in towns, has been ascribed to tobacco, but a possible contributory effect of the suspended matter of town air cannot yet be excluded finally. Iceland provides the example of a country where bronchial cancer is rare, the general consumption of tobacco small, and atmospheric pollution quite unlike that in England, though the history of Reykjavik is rather confused in this respect, as was pointed out above. In the course of years such comparative studies may enable one to assess the importance of these two factors."

For comparison Sir Ernest quotes figures for smoke estimations in the three countries.

$$
\begin{aligned}
& \text { Comparative Measurements of atmospherio Pollution } \\
& \text { Smoke, } \\
& \begin{array}{l}
\text { mean } \mathrm{mgm}_{\text {, in }} \\
100 \mathrm{~m}^{3} \text { air }
\end{array} \\
& \text { Steeffield } \\
& \text { February 1948: } 3 \text { foggy days } 173
\end{aligned}
$$

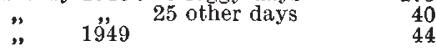

$$
\begin{aligned}
& \text { Salford (Manchester) } \\
& \text { November } 1952 \text { to January } 1953 \quad 76 \\
& \text { Leicester } \\
& \text { Whole year } \\
& \text { Oslo } \\
& \text { 1953, February, March November } \\
& \text {, April to July } \\
& \text { Reykjavik } \\
& \text { 1953, August, September } \\
& \text { "October, November }
\end{aligned}
$$

The report goes on to say: "In the smoke papers from Salford the following polynuclear hydrocarbons have been identified, and some of these have been estimated quantitatively : anthracene, pyrene, fluoranthene, perylene, $1: 2$-benzpyrene, $3: 4$-benzpyrene, 1 : 12-benzperylene, anthanthrene and possibly an alkyl pyrene and $1: 2$-benzanthracene. 'The relative proportions of these hydrocarbons, e.g., the ratio pyrene: $3: 4$-benzpyrene, differ in various products of combustion and such comparisons provide an interesting subject for study".

Research at the London Hospital has given some startling results. Croton oil, the best-known cocarcinogen (or promotor), can induce tumours when it is painted on mouse skin, provided the skin has 